\title{
VALEUR ÉNERGÉTIQUE ET AZOTÉE D'UN TOURTEAU DE COLZA EXEMPT DE THIOGLUCOSIDES
}

\author{
J. DELORT-LAVAL et L. P. BORGIDA \\ Laboratoire de Recherches sur la Conservation et l'Efficacité des Aliments, \\ Centre national de Recherches zootechniques, I. N.R. A., \\ 78 - Jouy-en-Josas
}

\section{RÉSUMÉ}

A dose élevée, le tourteau de colza déprime la vitesse de croissance du porc. Cet effet est attribué à la présence de produits de dégradation des thioglucosides libérés par voie chimique ou enzymatique au cours de la délipidation de la graine.

Le tourteau préparé à partir d'une variété de graines de colza (Bronowski) exempte de thioglucosides peut être distribué au porc comme seule source azotée; ajouté à un régime protéiprive équilibré par ailleurs, il a été comparé à un tourteau de soja cuit supplémenté en méthionine par la méthode des bilans (Тномаs-Mitchell) sur des porcs de $35-60 \mathrm{~kg}$. Les coefficients d'utilisation digestive apparente et réelle, les valeurs biologiques et l'utilisation protidique nette sont respectivement pour le colza de 80,7, $91,2,72,0,65,6$ et pour le soja de $84,0,92,6,73,6,68,9$. Les valeurs biologiques sont comparables à celles calculées à partir de l'index d'acides aminés essentiels (OSER) soit respectivement $7 \mathrm{I}, 5$ et 75,3. Les digestibilités réelles de l'azote des 2 tourteaux sont comparables, mais l'utilisation digestive apparente de l'azote, de la cellulose et de l'extractif non azoté du tourteau est médiocre.

\section{SITMMARY \\ ENERGY AND PROTEIN VALUE \\ OF THIOGLUCOSIDE FREE RAPE-SEED OIL MEAL,}

High doses of rape-seed oil meal decrease the growth rate of the pig. This effect is due to the presence of degradation products of thioglucosides released by chemical or enzymatic way during the delipidation of the seed.

The oil meal prepared from a variety of rape-sceds (Bronowski) without thioglucosides can be distributed to pigs as sole source of proteins ; added to a protein-free diet, otherwise balanced, it was compared to a toasted soybean oil meal, surnlemented with methionine, by means of the balance method (Thomas-Mitchell) using pigs between 35 and $60 \mathrm{~kg}$. The apparent and real digestive utilization coefficients, the biological values and the net protein utilization were the following : rape-seed $80.7,91.2,72.0,65.6$ and soybean : $84.0,92.6,73.6,68.9$. The biological values were similar to those calculated from the essential amino acid index (OSER), i. e. 7 1.5 and 75,3 respectively. The real protein digestibilities of the 2 oil meals were similar, but the apparent digestive utilization of the protein, the cellulose and the nitrogen free extract of the oil meal was bad. 